\title{
När självskadebeteendet blir en del av identiteten
}

\author{
Mitt självskadebeteende började när jag var 14 år. Inledningsvis var \\ det hela ganska oskyldigt, men när jag kom till BUP accelererade \\ beteendet plötsligt kraftigt. Jag vågar i efterhand påstå att vården \\ i sig var en av orsakerna till att mitt beteende förvärrades istället \\ för att förbättras. Hur kunde det bli så? Och kanske viktigast av allt - \\ hur skulle man ha gjort istället?
}

Jag var 14 år och gick i åttonde klass. En dag spelade vi bandy på idrotten i skolan och någon råkade träffa mig på handen med sin klubba. Slaget efterlämnade ett djupt hack på handryggen, som så småningom blev infekterat. Men vad vi inte visste då var att det såret också skulle bli början på självskadebeteendet som sedan skulle följa mig i många år. Medvetet rev jag upp såret så att det blev större och djupare, utan att jag visste varför. En tid senare tog jag för första gången till rakbladet.

\section{Inlagd}

Några månader senare blev jag inlagd på en barnpsykiatrisk akutavdelning. Året var 1999 och jag lades i första hand in på grund av självsvält, men också med ett självskadebeteende som efter många års självnedvärderande tänkande hade blommat ut. Jag har aldrig tvivlat på att jag behövde läggas in den där gången. Jag var inne i en självdestruktiv spiral som behövde brytas. Men däremot har jag funderat mycket på vad som hade hänt om jag hade blivit utskriven efter tre veckor, som det var tänkt från början. Det hade säkert inte blivit bra direkt. Jag hade kanske behövt läggas in fler gånger, för att bryta negativa cirklar. Men någonstans tror jag inte att det hade blivit så illa om jag inte blivit kvar på akutavdelningen i två år.

Mycket har förändrats i synen på självskadebeteende sedan slutet på 90- talet. Idag kan min hemstad Lund erbjuda både unga och vuxna den behandlingsform som på många sätt har förändrat synen på självskadebeteende i Sverige, dialektisk adfaerdsterapi (DAT). 1999 höll man fortfarande på att starta upp denna verksamhet, som dessutom var reserverad för vuxna patienter med borderline personlighetsstörning. Kåver och Nilsonne skriver i sin bok «Dialektisk beteendeterapi vid borderline personlighetsstörning» (2002): «Enligt vår erfarenhet har patienterna oftast mer nytta av korta, planerade inläggningar om omständigheterna är sådana att inläggning behövs» (s. 91). Denna inställning har blivit alltmer vedertagen inom svensk psykiatri, men fortfarande händer det att självskadande patienter, liksom jag, blir kvar i månader och år på sjukhus.

\section{Livet utanför gick vidare}

Jag hade fyllt 15 år när jag blev inlagd, men när man är 15 år händer mycket. Den sommaren åkte min bästa vän på läger och träffade sin första pojkvän. Hon började så småningom nionde klass, och när det började en ny flicka i klassen glömdes jag bort. Jag hade fått sluta spela teater när jag blev inlagd. Mina vänner, mina intressen och min familj efterlämnade ett hål i mitt hjärta - ett hål som så småningom fylldes upp med annat. Mina friska vänner ersattes av ungdomar som var lika självdestruktiva som jag själv, mina föräldrar ersattes av personal och mina intressen ersattes av ätstörningar och självskadande beteende. Jag ville inte längre bli «frisk», av rädsla att förlora det enda jag hade. Självskadandet accelererade och snart stod läkarna inför ett nytt dilemma; skulle de skriva ut mig från sjukhuset, till en miljö som möjliggjorde ett normalt liv men som också medförde en risk för mitt liv? Eller skulle jag stanna kvar på sjukhuset, i en sjuk miljö som omöjliggjorde ett friskt liv men där man fysiskt kunde hindra mig att skada mig själv? Det handlade, som så ofta, om att väga möjligheter och risker mot varandra.

Efter två år fattade en modig läkare beslutet att skriva ut mig, trots att mitt självskadebeteende nu var av livshotande karaktär. Jag gjorde allt för att komma tillbaka till den instängda, strukturerade miljön som jag på ett sätt avskydde men som samtidigt var den enda värld jag kände mig trygg i. Jag fick åka till sjukhuset för medicinsk vård av mina självskador, men sedan skickades jag hem igen.

\section{Att vårda det friska}

Idag är jag tacksam för att läkaren vågade ta den risk det innebar att skriva ut mig. Det var en kaotisk första tid, men efter något år kunde jag långsamt bygga upp mitt liv igen. Denna gång med friska byggstenar.

- Om inte du vill bli frisk så kan jag förstå det, sa min psykolog till mig vid något tillfälle. - Du kan ju inte veta vad det innebär att må bra! Att känna att livet inte är perfekt, men det är i alla fall mer bra än det är dåligt. Den dagen du får smaka på det friska livet kommer mycket att gå av sig själv.

Denna erfarenhet har fått mig att som vuxen sjuksköterskestudent att intressera mig mycket för Aaron Antonovskys teorier om salutogenes. Istället för att fråga sig vad som skapar ohälsa kan man fråga sig vad det är som gör att vi blir friska och bibehåller hälsan. Jag tror att ett problem inom vården många gånger är att så mycket fokus läggs på det som inte fungerar i en patients liv, och att de resurser och styrkor som faktiskt finns där glöms bort. Hur formar det självbilden hos en sårbar15-åring? Jag skulle vilja säga, att lika viktigt som det var att hjälpa mig med mina problem, borde det ha varit att hjälpa mig bibehålla mina resurser. Hur hade man kunnat uppmuntra och utveckla mina intressen för teater? Hur hade man kunnat stötta min bästa vän, som faktiskt var en vän med god inverkan på mig? Hur hade man kunnat hjälpa mina föräldrar att orka?

Att vårda sjukdomar och att lösa problem är viktigt, men många gånger tror jag det är lika viktigt att vårda och stärka den friska människa som alltid finns gömd någonstans där bakom.

\section{Sofia Åkerman \\ www.sofiaakerman.com}

Manuskriptet ble mottatt 4.1. 2009 og godkjent 8.1. 2009. Medisinsk redaktør Erlend Hem. 